LUBLIN STUDIES IN MODERN LANGUAGES AND

LITERATURE 40(1), 2016, HTTP://WWW.LSMLL.UMCS.LUBLIN.PL, HTTP://LSMLL.JOURNALS.UMCS.PL

\author{
Bożena Kucała \\ Jagiellonian University \\ al. Mickiewicza 9A, 30-120 Cracow, Poland
}

\title{
Memory and the Splitting of the Self in John Banville's The Sea
}

\begin{abstract}
This article explores the problem of the self in The Sea by John Banville. The narrator's professed lack of a stable identity coexists with a multiplication of his different "selves." It is argued that the splitting of the self in Banville's novel is more complicated than the split between the narrating self and the subject of narration, common to retrospective first-person narratives. Due to the intensely visual and time-defying nature of his memory, the protagonist seems to revive the past and achieves the sense of a simultaneous existence as two beings. The narrator's need to locate himself at a fixed point in his narrative, combined with his inability to adopt a definitive perspective, results in a permanent erosion of identity.

Keywords: John Banville, The Sea, memory, selfhood, identity
\end{abstract}

In his overview of John Banville's novels Derek Hand observed that after the science tetralogy ${ }^{1}$ his fiction had begun to move inwards,

\footnotetext{
1 The tetralogy includes: Doctor Copernicus (1976), Kepler (1981), The Newton Letter (1982) and Mefisto (1986). Indeed, these novels may be said to prefigure later tendencies in Banville's fiction. As Hand notes, the disintegration of master narratives and the epistemological crisis depicted in the science books have "ontological repercussions" for their protagonists (2002:118).
} 
towards "an investigation of the self" (2002:21) and had narrowed its focus to the individual - "the nature of individual identity and how it is created and sustains itself in the world and in connection with others" (Hand 2002:116-17). The Sea confirms the pertinence of this observation, although Hand's indication of Banville's concerns might also be expressed in negative terms: Banville's fiction demonstrates how the individual cannot establish and sustain a stable identity. Mark O'Connell notes that one of the most striking aspects of Banville's fiction is "its unflagging fascination with postures and impostures. Almost all of his protagonists are performers of roles, men who are constantly arranging themselves in some or other type of pose" 2011:328). Brendan McNamee emphasises the interconnectedness of self-obsession, self-division and inauthenticity in his protagonists (cf. O'Connell 2011:328) whereas Hedwig Schwall describes Banville's novels as "one big enterprise to deconstruct the illusion of (id)entity" (ibid.). The writer himself said in an interview: "There is no answer to these questions of identity and authenticity ... All you can do is try to find new ways of posing the questions" (qtd. in Facchinello 2010:35).

The Sea (2005) is an intriguing attempt to ask the old questions anew. Max Morden, the narrator-protagonist of the novel, is an elderly man revisiting the place where he once spent his holidays with his parents. The narrator recovers his memories of those times and, while doing so, struggles with his lack of an integrated selfhood. The novel is a first-person retrospective narrative, a nostalgic recollection of a memorable summer, an elegy for the protagonist's wife and an endeavour to recover an irrecoverable past. Yet The Sea should be read primarily as a record of the protagonist's inner division, going back to the birth of his self-consciousness, which was accompanied by a lifelong sense of self-estrangement. Elke D'hoker remarked that in Banville's early fiction his "never fully reliable first-person narrators can be observed in the process of representing their traumatic past, their tormented thoughts and divided selves in a coherent narrative so as to achieve a sense of self that is unitary, solid and clear" (2004:2). Compared with his fictional predecessors, the narrator of The Sea does not aim at a coherent narrative nor at a solid, unitary self. Indeed, the 
novel is marked by an unresolved contradiction between the narrator's need to establish himself at a suitable vantage point in his narrative and his inability to adopt a definitive perspective, and this contradiction results in a splitting of his identity. Just as in the earlier novels, Book of Evidence or Ghosts, the narrator of The Sea introduces "a curious distinction between the I who perceives and the I (myself) who is perceived" (D'hoker 2004:175), but, unlike the other protagonists, makes no attempt to erase it.

In Oneself as Another, Paul Ricoeur explores factors which determine individual identity. One category of the "individualizing operators" he distinguishes includes proper names because "a single name, among the list of available names, permanently designates a single individual in opposition to all the others of the same class." Proper names confirm people's identity and their selfhood. Another category includes personal pronouns such as "I" as well as deictic terms which in each case designate "the relation to the utterance, taken as a fixed point" (Ricoeur 1994:28-30). ${ }^{2}$ In Banville's novel, the protagonist's identity becomes problematic on both counts. The name "Max" by which he designates himself and by which he is known to others is not his real name. He discloses this fact only obliquely, by quoting his mother's objection to his use of a false name. ${ }^{3}$

Far more interesting and more problematic, however, is the way the protagonist refers to himself in his narrative, which includes his use of personal pronouns. Even though Max remains at the centre of his narrative, his continual employment of the pronoun "I" stands in stark contrast to a revealing dream in which his typewriter "was

\footnotetext{
${ }^{2}$ The third category is a definite description, which "consists in creating a class that has but a single member through the intersecting of well-chosen classes (man, walk, moon)" (Ricoeur 1994:28). In this respect, too, Max's identity remains obscure - so little does he disclose concerning his social or professional life that it is practically impossible to classify him. In his own narrative he comes across as a man without qualities.

${ }^{3}$ Monica Facchinello draws attention to the recurrence of this name in Banville's novels and concludes that "Max is more an alias than a name" and as such it "identifies without characterising" (2010:36).
} 
lacking the word $I$. The letter $I$, that is, small and large" (Banville 2006:71). ${ }^{4}$ Paradoxically, in the two-sentence paragraph in which this dream is recounted the large " $\mathrm{I}$ " denoting the narrator's identity occurs as many as three times. David Grylls notes this apparent contradiction and claims that the narrator's lack of self experienced in the dream "is not a problem afflicting his waking self: precious, sensitive, narcissistically verbose, he is glued to the first-person pronoun" (Grylls 2005). However, it is impossible to reconcile the denial of one's identity with the necessity to assert oneself as the author of one's own narrative. With regard to Banville's novel it seems more appropriate to claim that the profusion of first-person pronouns, combined with their uncertain referent, illustrates rather than undermines the absence of a definable selfhood which the protagonist intuits in his dream.

Max's narrative - and this also appears true of his life - is framed by two events: the death of the Grace twins whom he met as a teenage boy while on holiday with his parents, and the recent death of his wife. By his own admission, that holiday by the sea, and in particular his relationship with Chloe Grace, marked the birth of his sense of identity by making him aware of his otherness:

She was I believe the true origin in me of self-consciousness. Before, there had been one thing and I was part of it, now there was me and all that was not me. But here too there is a torsion, a kink of complexity. In severing me from the world and making me realise myself in being thus severed, she expelled me from that sense of the immanence of all things, the all things that had included me, in which up to then I had dwelt, in more or less blissful ignorance. Before, I had been housed, now I was in the open, in the clearing, with no shelter in sight. I did not know that I would not get inside again, through that ever straitening gate ( $S 168$ ).

It was when he met the Graces that he ceased to take himself for granted and began to pursue the dream of being someone else. Although at that time his desire centred mostly on social advancement, his subsequent worldly success (education, a higher social status, wealth) has done nothing to heal this inner breach. Accordingly, he defines his life as a "continuous rehearsal" ( $S$ 184), in

\footnotetext{
${ }^{4}$ Later abbreviated as $S$.
} 
which he is both the protagonist and the spectator, but feels that the real drama has never begun.

Max shares with other Banville narrators a dissatisfaction with his original identity. In fact, in the words of Monica Facchinello, "all Banville's protagonists are men who have fabricated a new identity for themselves replacing the one bequeathed to them at birth" (2010:34). Towards the end of his narrative Max confesses:

From earliest days I wanted to be someone else. ... It was not what I was that I disliked, I mean the singular, essential me - although I grant that even the notion of an essential, singular self is problematic - but the congeries of affects, inclinations, received ideas, class tics, that my birth and personality had bestowed on me in place of a personality. In place of, yes. I never had a personality, not in the way that others have, or think they have. I was always a distinct no one, whose fiercest wish was to be an indistinct someone ( $S 216)$.

The experience of exile and estrangement which accompanied the birth of his self-consciousness has haunted him all his life, and also was the essence of the dream which has now prompted the adult protagonist to return to the place of his holiday. The journey which Max makes in his dream turns out to be inconclusive; at the end of it he remains homeless, moving along a road with no destination in sight. Eoghan Smith describes the protagonist as suffering from "an intense solipsism," "wholly self-conscious and entirely unhoused" (2013:151).

The Sea shares with other retrospective narratives a split between two narrating voices or two narratorial identities. Nicola King observes that any autobiographical narrator is in the paradoxical situation of "knowing" and "not knowing," at the moment of narration possessing knowledge which s/he did not have at the time of the experience (2000:2-3). This split between the narrating self and the experiencing self has long been acknowledged in narrative theory. Drawing on Émile Benveniste's distinction between the énoncé and the énonciation, Gérard Genette avers that a temporal interval between the moment of the story and the moment of the narrating effectively produces two different heroes (or heroines): the one who narrates and gives his (or her) point of view is different from the one who is spoken 
of (1983:218). The narrator of The Sea occasionally perceives his younger self as another being, for example, in the episode when he remembers himself as a boy listening to the radio. The otherness of the boy is marked by the use of a third-person pronoun: "If that child dreaming by the wireless had been asked what he wanted to be when he grew up, what I had become was more or less what he would have described, in however halting a fashion, I am sure of it" ( $S$ 93).

On the level of narration, the diverse pronouns signify the difference between the narrating self and the subject of narration; on the ontological level, they expose the divergence between stages in the protagonist's personal development. It is a widely acknowledged paradox that personal identity is both permanent and mutable. The problem has been articulated by Ricoeur as a distinction between two different concepts of identity: identity as self (ipse) and identity as sameness (idem) (1991:73). The two intersect "with regard to permanence over time" (1991:75). Ricoeur claims that "narrative identity offers a solution to the aporias concerning personal identity" because the sense of connectedness of life may be achieved by telling oneself stories about it. In fictional narratives it is the plot that particularly helps to construct a character's identity by mediating between permanence and change (1991:76-77). The underlying assumption of Ricoeur's essay is that "knowledge of the self is an interpretation" and that narrative is a privileged form of that interpretation (1991:73).

In her book Memory, Narrative, Identity: Remembering the Self Nicola King stresses the crucial role of memory in the shaping of life narratives: "All narrative accounts of life stories, whether they be the ongoing stories which we tell ourselves and each other as part of the construction of identity, or the more shaped and literary narratives of autobiography or first-person fictions, are made possible by memory." She goes on to add that "the concept of the self" constructed in these narratives depends upon the processes of memory (2000:2-3). It was John Locke in An Essay Concerning Human Understanding who laid the foundations of modern ideas about personal identity by claiming that the sense of identity depends on the continuity of consciousness 
(cf. King 2000:2). Locke emphasises that "consciousness, as far as ever it can be extended - should it be to ages past - unites existences and actions very remote in time into the same person" (1894:458). "Person" is defined as "a thinking intelligent being, that has reason and reflection, and can consider itself as itself, the same thinking thing, in different times and places" (1894:448). Hence the philosopher makes identity reliant on memory, defined by him as "the storehouse of our ideas" (1894:193).

The role of memory in ensuring personal identity is recognised by the protagonist of The Sea, who acknowledges his connection with the boy he once was. His memory has preserved certain episodes from the past with such accuracy that he can easily breathe life into them. One such incident is the finding of a destroyed bird's nest:

I should not make too much of the moment, I am sure I was as sentimentally heartless as the next boy, but I can still see the gorse, I can smell the buttery perfume of its blossoms, I can recall the exact shade of those brown speckles, so like the ones on Avril's pallid cheeks and the saddle of her nose. I have carried the memory of that moment through a whole half century ( $S 159)$.

Memory generates a sense of continuity also by ensuring a model of permanence in time which Ricoeur calls "character." The term signifies "the set of lasting dispositions by which a person is recognized." These dispositions may be expressed through habits (Ricoeur 1994:121). Banville's narrator often refers to what might be called his lasting dispositions, e.g. "I have always been a moaner" ( $S$ 42), "I have always been strongly susceptible to the weather and its effects" ( $S$ 93). The references to continuity of experience in Max's narrative appear to confirm that "[i]t is commonly accepted that identity, or a sense of self, is constructed by and through narrative: the stories we all tell ourselves and each other about our lives" (King 2000:2).

However, Max's narrative, although obviously grounded in memory, in fact resists the form of story, or, to quote a narratological definition, "a series of real or fictitious events, connected by a certain logic or chronology" (Hawthorn 2000:227). The narrative flow in the book is disrupted so often as to induce the reader to look for an 
alternative structural pattern to a sequence of events. Max's account appears to be an array of disconnected episodes that constitute a collection of images rather that a story, and his memory is distinctly visual. The narrator's comment on one of his recollections is key to how his memory works: "I see the game as a series of vivid tableaux, glimpsed instants of movement all rush and colour" ( $S$ 125). Later Max notes: "Memory dislikes motion, preferring to hold things still" (S 221). His account unfolds against time rather than chronologically and overtly disrupts the temporal sequence. The protagonist's timedefying memory facilitates rapid shifts between past and present, which makes the account disjointed and fragmentary. Despite the vividness of the scenes he remembers from the past, he is unable to reconstruct the sequence of events that preceded or followed particular episodes. Consequently, the connections between his different selves typically depend on simultaneity rather than continuity.

There are numerous episodes in the novel when the protagonist seems to be present in both incarnations at once, as both his younger self and his present mature self, and hence the referent of the pronoun "I" becomes ambiguous. In other words, he has distinct identities not over time, but at the same time (or perhaps outside time). $\mathrm{He}$ experienced this split already in the dream which prompted him to revisit Ballyless. While dreaming, he was both the age he is now and a boy; he felt compassion "for myself, that is to say the dreamer that I was felt compassion for the self being dreamed" ( $S 25)$.

This division is more problematic than the disjunction between the narrating self and the subject of narration. Considering the chronology of the events, most of the narrative constitutes what Genette calls "subsequent narrating," that is narrating the action after it has been completed (1983:220). However, the protagonist tries to annihilate the temporal distance between the present and the past and often effectively achieves a sense of his simultaneous existence as more than one self. The illusion of being two persons at the same time, experienced in the dream, also can be attained due to the paradoxical operation of memory, which is nourished by temporal development but which may easily overpass linearity and chronology. 
Corresponding to the splitting of the referent of "I" is the employment of grammatical tenses to denote the narrator's subjective sense of time rather than the objective temporal sequence. Max admits: "The truth is, it has all begun to run together, past and possible future and impossible present" ( $S$ 96). The resultant impression of multiple temporal planes coexisting and blending is, as Elizabeth A. Weston argues, "inherent to the processes by which we both project the future and delve into the past in order to establish a sense of coherence in our selves that persists across time" (Weston 2010). Yet the disregard for chronology does not lead Max to arrive at a unified self; instead, it reinforces his inner division. Episodes from the past form a series of live images in the protagonist's mind, with the connections between them eroded by time. Contrasted with the large parts of his life which his memory has not preserved at all is the accuracy and vividness of the scenes that it has retained. The recollections become so intense as to enable the narrator to be reincarnated as his former self. For example, remembering the first time he found himself in the Graces' holiday house, he attains the sense of living the scene over again. From a narrative of the past, or "subsequent narrating," he switches to a record of what appears to be happening here and now, or "simultaneous narrating," to use Genette's term (1983:218-19). Accordingly, the narration begins to employ the present tense: "Let me linger here with [Mrs Grace] a little while, before Rose appears, and Myles and Chloe return from wherever they are, and her goatish husband comes clattering on to the scene" $(S$ 86). The intense looking at the pictures on "the wall of [his] memory" ( $S$ 224) has the potential to resurrect the figures in them, including himself. From seeing his younger self ("I see myself another day within the very sanctum itself [i.e. the Graces' house]" $(S 85))$ he becomes that self without ceasing to be the spectator-self: "So there I am, in that Edenic moment at what was suddenly the centre of the world, with that shaft of sunlight and those vestigial flowers - sweet pea? all at once I seem to see sweet pea - and blonde Mrs Grace offering me an apple that was however nowhere in evidence" $(S 89)$. 
The episode quoted below exemplifies the narrator's shift from subsequent to simultaneous narrating, accompanied by a shift from the past tense to the present tense and an oscillation of his selfhood between the boy who participates in the action and the elderly man who watches and narrates:

We three were the only ones on the beach. The misty grey air of evening had the feel of dampened ash. I see us turn and walk away towards the gap in the dunes that led to Station Road. A corner of Chloe's towel trails in the sand. I go along with my towel draped over one shoulder and my wet hair slicked down, a Roman senator in miniature. Myles runs ahead. But who is it that lingers there on the strand in the half-light, by the darkening sea that seems to arch its back like a beast as the night fast advances from the fogged horizon? What phantom version of me is it that watches us - them - those three children - as they grow indistinct in that cinereal air and then are gone through the gap that will bring them out at the foot of Station Road? (S 136-37)

The character often has the feeling of self-detachment, watching himself at a distance or existing in two places at once. Indeed, his purpose in revisiting Ballyless is not only to recollect the past but to be mentally transported back in time, in search of comfort and protection. The past becomes for him almost a place rather than a time gone by. Max confesses: "That is why the past is just such a retreat for me, I go there eagerly, rubbing my hands and shaking off the cold present and the colder future. And yet, what existence, really, does it have, the past? After all, it is only what the present was, once, the present that is gone, no more than that. And yet" ( $S$ 61). His daughter remarks, with unsuspected aptness, that he "live[s] in the past" $(S 60)$ - for Max, this is not merely a cliché.

In her overview of theories of memory Nicola King notes that there exist two contradictory basic models. One is predicated on the assumption that memory involves a process of interpretation: it revises or "translates" memory-traces in accordance with later knowledge (King 2000:4). This entails a recognition that there is no objective memory; whether the act of recollection is deliberate or involuntary, the past is always cloaked in interpretation (cf. Kalaga 2012:80). The other model, prevalent in our culture, uses the metaphor of memory as an archive (or a storehouse, as Locke would have it). In this model 
memory may be conceived of either as a storing space or a surface on which the past has impressed its trace (Kalaga 2012:80). The latter image goes back to Plato's dialogue Theaetetus, in which Socrates famously conceptualises memory as a wax tablet on which our perceptions and ideas are imprinted. ${ }^{5}$ Sigmund Freud, one of the founders of modern theories of memory, although aware of its active role in shaping our ideas about the past, envisaged the process of retrieving memories in terms of archaeological excavations - the past is believed to continue to exist somewhere, available for discovery by the remembering subject (cf. King 2000:12-13).

Banville's narrator clearly wants to believe in the latter model, even though implicit in his reflections is the belief that the private space of his memory ought to be protected from verification or confrontation with an external perspective. While reflecting on the lasting impact of Mrs Grace on his memory, Max evokes the Platonic metaphor: "No doubt for others elsewhere she persists, a moving figure in the waxworks of memory, but their version will be different from mine, and from each other's" (S 118-19). Rather than telling himself stories about his life, the narrator retrieves images. His private version of the space of memory is a collection of pictures, and "the wall of [his] memory" ( $S$ 224) functions like the Platonic block of wax. Although he acknowledges the pitfalls of memory and its capacity for distortion, he prefers to think of those recollections which his mind has retained as accurate enough to make the past available for re-entry. Hence Max affirms that "[r]eally, one might almost live one's life over, if only one could make a sufficient effort of recollection" ( $S$ 160). The protagonist discovers that the pictures in his mind must be refreshed if they are to be saved from oblivion, thus he

\footnotetext{
${ }^{5}$ Socrates: "Imagine, then, for the sake of argument, that our minds contain a block of wax [...]. Let us call it the gift of the Muses' mother, Memory, and say that whenever we wish to remember something we see or hear or conceive in our own minds, we hold this wax under the perceptions or ideas and imprint them on it as we might stamp the impression of a seal-ring" (Plato 1935:121).
} 
makes a conscious effort to restore and preserve the images in his mental collection. ${ }^{6}$

Max's picture gallery is his equivalent of the traditional idea of the archive. The archive, as the Polish philosopher Barbara Skarga observes in her essay on memory, is not organised according to any temporal structure (1995:17). In fact, the protagonist's pictorial retrospection is a rival mode of presentation to his "narrative identity," and this approach to recounting the past dominates in Banville's novel. The narrator's spatial concept of memory makes it possible for him to experience a simultaneous existence as an older and a younger self.

King notes that daily social discourse and a significant proportion of conventional autobiographical writing wrongly elides the distinction between the narrating "I" and the subject of the narration, treating them as if they were identical and overlooking the role of memory as a process (2000:3). This comment does not apply to Banville's novel, whose narrator is aware of the disjunction between his two selves when he invokes his past. Recalling vividly the scene when he first saw the Grace family during his holiday, the narrator wonders about his own location at the time: "Where am I, lurking in what place of vantage? I do not see myself" $(S 10)$. Therefore, memory may be said to perform a double and apparently self-

\footnotetext{
${ }^{6}$ Cf. John Locke in An Essay Concerning Human Understanding: "there seems to be a constant decay of all our ideas, even of those which are struck deepest, and in minds the most retentive; so that if they be not sometimes renewed, by repeated exercise of the senses, or reflection on those kinds of objects which at first occasioned them, the print wears out, and at last there remains nothing to be seen. Thus the ideas, as well as children, of our youth, often die before us: and our minds represent to us those tombs to which we are approaching; where, though the brass and marble remain, yet the inscriptions are effaced by time, and the imagery moulders away. The pictures drawn in our minds are laid in fading colours; and if not sometimes refreshed, vanish and disappear" (Locke 1894:196). The protagonist of The Sea makes a deliberate effort to preserve his memory of his wife: "I was thinking of Anna. I make myself think of her, I do it as an exercise. She is lodged in me like a knife and yet I am beginning to forget her. Already the image of her that I hold in my head is fraying, bits of pigments, flakes of gold leaf, are chipping off"' ( $S 215)$.
} 
contradictory role in Banville's novel: on the one hand it allows the protagonist to reconnect mentally with his younger self, thereby integrating different stages of his life and creating the kind of continuity of consciousness which Locke posited as the basis of selfhood, yet, on the other hand, by allowing him to mentally bring back the past, it divides him into two co-existent selves. ${ }^{7}$ The latter occurrence is frequently marked by the striking double use of the pronoun "I" to designate both his narrating self (or, rather, his perceiving self) and his own figure animated on the wall of his memory.

Terms commonly used in analysing narrative such as "point of view" or "perspective" cannot be overemphasised with regard to The Sea. Whereas the novel is very much about acts of looking and the experience of being subjected to someone else's scrutiny, the narrator's continued difficulties with adopting an appropriate perspective are directly related to his unstable sense of selfhood. Just as his selfhood is volatile, so are the narrator's perspective and the focus of his narrative.

A link between the framing events of the narrative emerges. Memories of the Grace twins' death by water are conflated with the sense of drowning which the protagonist himself experiences on hearing the news of his wife's death. If the encounter with the Graces caused an inner split at the outset of his conscious life, then his wife had been for the narrator "the fairground mirror" ( $S$ 216) which offered him the Lacanian illusion of a unified, acceptable image of himself. Anna provided the crucial external perspective which the protagonist needed in order to maintain a semblance of inner cohesion. ${ }^{8}$ Mark O'Connell even suggests that Max is perhaps "not so

\footnotetext{
${ }^{7}$ In the conclusion of her essay "Tożsamość ja i pamięć" [The identity of I and memory] Barbara Skarga remarks that memory, on the one hand, is essential in constructing integrated selfhood; on the other hand, it constantly threatens to dismantle it (1995:18).

${ }^{8}$ Max says: "The philosophers tell us that we are defined and have our being through others. Is a rose red in the dark? In a forest on a far planet where there are no ears to
} 
much devastated by the loss of his beloved wife as he is gripped by narcissistic rage over having been deprived of a way of seeing himself, of a means of self-definition" (2013:14). Her recent death has confronted the protagonist with the loss of any outside prop for his selfhood. Therefore the protagonist's crisis, although obviously related to his bereavement, is primarily a crisis of identity. The recurrent doubling of the self in his narration, rather than augmenting selfhood, brings about an attenuation of his sense of identity.

\section{Bibliography}

Banville, J. (2006) [2005]: The Sea. London: Picador.

D'hoker, E. (2004): Visions of Alterity: Representation in the Works of John Banville. Amsterdam-New York, NY: Rodopi.

Facchinello, M. (2010): "The Old Illusion of Belonging": Distinctive style, bad faith and John Banville's The Sea." Estudios Irlandeses. 5: 33-44.

Genette, G. (1983): Narrative Discourse. An Essay in Method. Trans. Jane E. Lewin. Ithaca, NY: Cornell University Press.

Grylls, D. (2005): "The Sea by John Banville." The Sunday Times, 12 June. http://www.thesundaytimes.co.uk/sto/culture/books/article136819.ece

Hand, D. (2002): John Banville: Exploring Fictions. Dublin: Liffey Press.

Hawthorn, J. (20002): A Concise Glossary of Contemporary Literary Theory. London: Edward Arnold.

Kalaga, W. (2012): Pamięć, interpretacja, tożsamość [Memory, interpretation, identity]. Teksty Drugie. 1-2: 39-58.

King, N. (2000): Memory, Narrative, Identity. Remembering the Self. Edinburgh: Edinburgh University Press.

Locke, J. (1894): An Essay Concerning Human Understanding. Vol. 1. Collated and annot., with prolegomena, biogr., crit., and historical by Alexander Campbell Fraser. Oxford: Clarendon Press.

O'Connell, M. (2011). On not being found: A Winnicottian reading of John Banville's Ghosts and Athena." Studies in the Novel. 43.3: 328-42. http://dx.doi.org/10.1353/sdn.2011.0044

O’Connell, M. (2013): John Banville’s Narcissistic Fictions. Basingstoke: Palgrave Macmillan.

hear that a falling tree makes a crash? I ask: who was to know me, if not Anna? Who was to know Anna, if not I?" (S 217) 
Plato (1935): Plato's Theory of Knowledge: The Theaetetus and the Sophist of Plato. Transl. with a running comment. by Francis Macdonald Cornford. London: Kegan.

Paul, Trench, Trubner \& Co. Ltd.; New York: Harcourt, Brace and Company.

Ricoeur, P. (1991). Narrative identity. Philosophy Today 35.1: 73-81.

Ricoeur, P. (1994): Oneself as Another. Trans. Kathleen Blamey. Chicago and London: University of Chicago Press.

Rossington, M., Whitehead, A. (ed.) (2007): Theories of Memory. A Reader. Edinburgh: Edinburgh University Press.

Skarga, B. (1995). Tożsamość ja i pamięć [The identity of I and memory]. Znak 47.5: 4-18.

Smith, E. (2013). John Banville: Art and Authenticity. Oxford: Peter Lang.

Weston, E. A. (2010). Narrating Grief in Virginia Woolf's Jacob's Room and John Banville's The Sea. "PsyArt." Academic Search Complete 